University of Nebraska - Lincoln

DigitalCommons@University of Nebraska - Lincoln

2016

The Grand Ethiopian Renaissance Dam: Source of Cooperation or Contention?

Meron Teferi Taye

Tsegaye Tadesse

Gabriel B. Senay

Paul Block

Follow this and additional works at: https://digitalcommons.unl.edu/natrespapers

Part of the Natural Resources and Conservation Commons, Natural Resources Management and Policy Commons, and the Other Environmental Sciences Commons

This Article is brought to you for free and open access by the Natural Resources, School of at DigitalCommons@University of Nebraska - Lincoln. It has been accepted for inclusion in Papers in Natural Resources by an authorized administrator of DigitalCommons@University of Nebraska - Lincoln. 


\section{The Grand Ethiopian Renaissance Dam: Source of Cooperation or Contention?}

\begin{abstract}
Meron Teferi Taye
Research Associate, Dept. of Civil and Environmental Engineering, Univ. of Wisconsin-Madison, 1415 Engineering Dr., Madison, WI 53706 (corresponding author).E-mail: meron.t.taye@gmail.com; taye2@wisc.edu
\end{abstract}

\section{Tsegaye Tadesse}

Associate Professor, National Drought Mitigation Center, School of Natural Resource, Univ. of Nebraska-Lincoln, 3310 Holdrege St., Lincoln, NE 68583-0988.

\section{Gabriel B. Senay}

Research Physical Scientist, USGS Earth Resources Observation and Science (EROS) Center, North Central Climate Science Center, Colorado State Univ., Fort Collins, CO 80523-1499.

\section{Paul Block}

Assistant Professor, Dept. of Civil and Environmental Engineering, Univ. of Wisconsin-Madison, 1415 Engineering Dr., Madison, WI 53706.

Forum papers are thought-provoking opinion pieces or essays founded in fact, sometimes containing speculation, on a civil engineering topic of general interest and relevance to the readership of the journal. The views expressed in this Forum article do not necessarily reflect the views of ASCE or the Editorial Board of the journal.

\section{DOI: 10.1061/(ASCE)WR.1943-5452.0000708}

\section{Introduction}

This paper discusses the challenges and benefits of the Grand Ethiopian Renaissance Dam (GERD), which is under construction and expected to be operational on the Blue Nile River in Ethiopia in a few years. Like many large-scale projects on transboundary rivers, the GERD has been criticized for potentially jeopardizing downstream water security and livelihoods through upstream unilateral decision making. In spite of the contentious nature of the project, the authors argue that this project can provide substantial benefits for regional development. The GERD, like any major river infrastructure project, will undeniably bring about social, environmental, and economic change, and in this unique case has, on balance, the potential to achieve success on all fronts. It must be stressed, however, that strong partnerships between riparian countries are essential. National success is contingent on regional cooperation.

\section{Energy Development and the Grand Ethiopian Renaissance Dam}

Insufficient energy supply, minimal infrastructure, and weak economies are common characteristics of most developing countries. Sub-Saharan Africa, and particularly East Africa, comprises a collection of such countries of whom a strikingly large number have low human development indicators (UNDP 2014). Many of these low-income countries are primarily reliant on rain-fed agriculture and thus highly vulnerable to variations in seasonal rainfall, particularly recurrent drought (IWMI 2016). Extreme hydroclimatic conditions often impose significant negative impacts across scales, ranging from household to regional to national levels that span various sectors, including agriculture, energy, industry, transport, health, and ecosystems (Grey and Sadoff 2006; Di Falco et al. 2012; Sadoff et al. 2015). Mitigating these impacts is crucial for sustainable development.

The energy sector is one of the least developed in Africa, especially in the Sub-Saharan region. The Africa Progress Report (2015) indicates the desperate shortage of electricity in SubSaharan African countries, with average consumption at $162 \mathrm{kWh}$ per capita per year, excluding South Africa. This is strikingly low compared to the $7,000 \mathrm{kWh}$ per capita per year global average. Ethiopia's consumption is also one of the lowest at $57 \mathrm{kWh}$ per capita per year as estimated in 2012 (World Bank 2015). The report also highlights how Africa's energy deficit stands in stark contrast to the region's potential; Ethiopia, for example, has only developed approximately $10 \%$ of its hydropower capacity (USAID 2015; MoFED 2010; Bureau of Reclamation 1964). Considering this and numerous studies that demonstrate parallels between managing hydrological variability and economic growth (e.g., World Bank 2006; FDRE 2008; Sadoff et al. 2015), the Ethiopian government has prioritized hydroelectric expansion to support its economic development goal of $11 \%$ GDP growth rate per annum (MoFED 2010). This has led to recent construction of a number of hydropower projects (Table 6.1 in Cuesta-Fernández 2015), of which the GERD is the largest. The economic implications of large-scale water storage have often been debated; however, more recently the benefits of storage have been noted in both qualitative and empirical studies (e.g., SIWI 2005; World Bank 2006; Grey and Sadoff 2007; Sadoff et al. 2015), suggesting that greater water availability has a significant and positive causal effect on countrylevel economic growth. Sub-Saharan African countries have remarkably low per capita water storage compared with most middle-income and upper-income countries (Grey and Sadoff 2006), thus increasing capacity may lead to positive development and substantial gains not just in energy, but other sectors as well.

Ethiopia's GERD, under construction since 2011, straddles the Blue Nile River close to the Ethiopian-Sudanese border (Fig. 1). Estimated to cost almost $\$ 5$ billion (Arjoon et al. 2014), the Ethiopian-financed dam will be a roller compacted and reinforced structure $1,780 \mathrm{~m}$ long and $145 \mathrm{~m}$ high, making the dam the largest in Africa (Abdelhady et al. 2015). Two powerhouses consisting of 16 Francis Turbines are planned to provide 6,000 MW of installed capacity (Salini Impregilo 2015), with two turbines installed at a lower elevation to facilitate power generation prior to dam completion. Construction of high-voltage transmission lines from the GERD to domestic locations and to neighboring countries (e.g., Sudan and Kenya; Cuesta-Fernández 2015) is underway. Total reservoir storage capacity will equal 74 billion $\mathrm{m}^{3}$, creating a $1,874 \mathrm{~km}^{2}$ lake that extends $246 \mathrm{~km}$ upstream when full. The reservoir is partially supported by a rock-filled and concrete-lined saddle dam located on the left bank, one of the largest in the world 


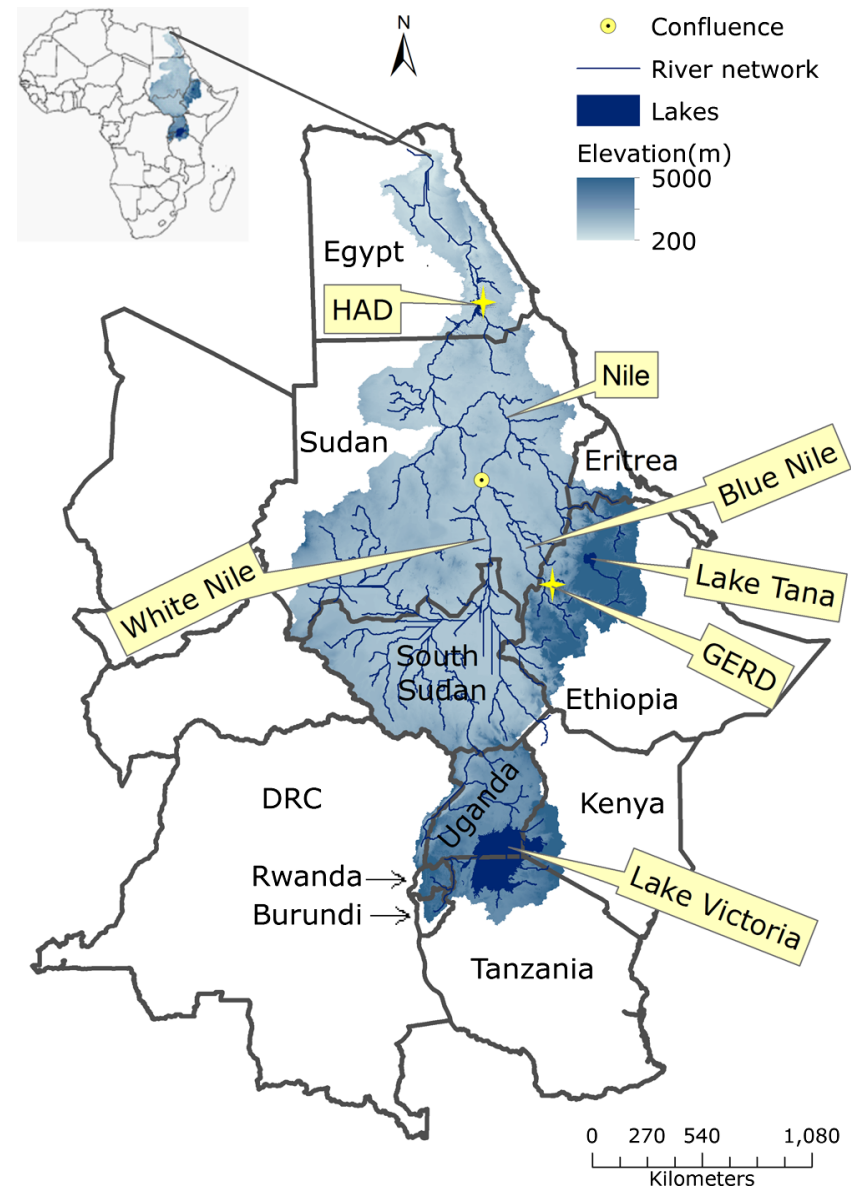

Fig. 1. Nile basin location in Africa including riparian countries and the forthcoming GERD in Ethiopia and the HAD in Egypt

at a length of $5.2 \mathrm{~km}$. Inflow to the reservoir site averages 48 billion $\mathrm{m}^{3}$ annually (Whittington et al. 2015), dominated by the main rainy season occurring in June through September (Taye et al. 2015). No water consumption activities or diversions are planned for the reservoir behind the GERD (ENPoE 2013).

\section{Pros and Cons of the GERD Project}

Investments in large dam projects are often controversial. Supporters often denote benefits such as flood control, water supply, and hydroelectric generation, while critics frequently highlight permanent ecosystem changes, modification of river flows, reduction of fish passage and sediment accumulation, and community displacement (WCD 2000). In 2000, the World Commission on Dams (WCD) published a comprehensive report on large dams (defined as dams greater than $15 \mathrm{~m}$ in height and storage capacity greater than 3 million $\mathrm{m}^{3}$ ), recommending that sustainable improvements to human welfare from economic, social, and environmental perspectives be demonstrated prior to construction (WCD 2000). The report emphasizes that the large dam debate should clearly extend beyond infrastructure to include environmental impacts, sustainability, economic and financial aspects, and equitable sharing of project costs and benefits across the region.

In light of the WCD report, the GERD is a controversial project in the Nile basin (Chen and Swain 2014), particularly considering the long-standing agreement between Egypt and Sudan, namely the 1959 Nile Treaty. This agreement allocates 55.5 billion and 18.5 billion $\mathrm{m}^{3}$ of the Nile River water to Egypt and Sudan, respectively; an additional 10 billion $\mathrm{m}^{3}$ are lost to infiltration and evaporation from Lake Nasser. These allocations and losses account for the annual average total of 84 billion $\mathrm{m}^{3}$ reaching the High Aswan Dam (HAD) (Murakami 1995). No consumptive allocations to other upstream riparian countries (Ethiopia, Uganda, Kenya, Tanzania, Rwanda, Burundi, Democratic Republic Congo (DRC), and Eritrea; Fig. 1) are prescribed. In response to the GERD, downstream countries (Sudan and Egypt) have raised concerns regarding the possible reduction of water, constituting a breach of the 1959 Treaty. Ethiopia and riparian countries on the White Nile River contest that they are not party to the 1959 Treaty and are entitled to an "equitable share" as long as there is no significant harm to downstream users. This stance was formalized through the recent Cooperative Framework Agreement, although unsurprisingly Egypt and Sudan did not sign on (NBI 2015).

Numerous studies highlight the potential negative impacts of the GERD on Egypt and Sudan (e.g., Chen and Swain 2014; J-WAFS 2014; Ahmed and Elsanabary 2015; Bastawesy 2015). Chen and Swain (2014) evaluate strategic priorities, sustainability standards according to the WCD's framework, and geopolitical significance, concluding that project planning and protocol has largely ignored the WCD's guidelines and offered limited transparency. A major concern they present is the estimated displacement and relocation of over 12,000 people, which is substantial but smaller than other large dam projects (Whittington et al. 2015). International Rivers (2015) estimates a total displacement of 40 to 80 million people worldwide because of large dams, most of them in China and India. While the displacement of people at any rate is undesirable, compared to the 1 million people displaced by the Three Gorges Dam in China to generate 22,000 MW (National Geographic 2010), the 12,000 displaced by the GERD (Chen and Swain 2014) to generate 6,000 MW is notably less.

Most people living in proximity to the dam are impoverished subsistence farmers, fisher-people, and hunters (Veilleux 2013). Preserving this rural/traditional lifestyle (with no dam) may be preferable to some, however others argue that potentially raising millions of people out of poverty through energy and economic growth outweighs preserving traditional lifestyles and some environmental damages (Bekele and Lautze 2009). Additionally, they argue, compensation is provided for displaced people (Abdelhady et al. 2015; Fortin 2014). The expected impact on cultural heritage loss is low as the location of the GERD is in a sparsely populated part of Ethiopia.

Reductions in downstream river flows will likely be most significant during the reservoir filling stage. While this is consequential for both Sudan and Egypt, only the latter is largely dependent on the Nile as a sole water source for all water related activities. Abdelhaleem and Helal (2015) conclude that a reduction of more than 5-15\% may significantly affect Egypt's water supply, irrigation, and safe navigation, however Mulat and Moges (2014) find that the filling period would not adversely affect Egypt's ability to irrigate. Zhang et al. (2015) provide a set of plausible filling polices and associated average reduction in streamflow, finding that impounding $10 \%$ (25\%) of monthly streamflow during the first 5 years of filling may result in a corresponding average reduction of $6 \%(14 \%)$ at Lake Nasser, behind Egypt's HAD. These figures may vary significantly, between 0.6 and $15.4 \%$, depending on the hydro-climatic conditions of the first few years of filling. According to Mulat and Moges (2014), a reduction in annual energy production from the HAD is estimated at $12 \%$ and $7 \%$ during and after the filling stage, respectively, under a 6-year filling period plan, however this assumes that the HAD's operations do not change. Thus, Egypt may incur economic losses during the filling stage, which may be further affected by hydro-climatic conditions and Sudan's level of withdrawals (Kahsay et al. 2015). 
According to the Ethiopian government (MoFED 2010), hydroelectricity from the GERD is expected to primarily satisfy national demand long-term, with surpluses exported to neighboring countries. However, since GERD production is likely to outpace domestic consumption due to insufficient infrastructure in the near future (e.g., peak demand was approximately 1,500 MW in 2014; World Bank 2014), exports to neighboring countries are highly likely (EAPP 2005). In 2014 Ethiopia generated 3,967 GWh of surplus energy, with projections for the coming years at approximately 20,000 GWh (Cuesta-Fernández 2015). Given this domestic and regional influx of energy, and simultaneously considering various hydrologic and withdrawal scenarios, the expected positive impact of the GERD on real GDP in the Eastern Nile region may be $5.5-8.8 \%$ during both the filling and operational stages (Kahsay et al. 2015). In addition, a 5.5\% increase in employment of unskilled labor in Ethiopia is estimated during the construction stage of the project (Kahsay et al. 2015).

The minimum annual net benefit for Sudan and Egypt is expected to increase from $\$ 4.9$ to $\$ 5.6$ billion in the agriculture and energy sectors with the GERD online; much of this increase is a result of the GERD's ability to provide supplemental flow (Kahsay et al. 2015; Arjoon et al. 2014). The availability of regulated streamflow for downstream countries better supports hydropower generation and provides options for year-round irrigated agriculture. This is particularly the case for Sudan as the Roseries dam reservoir is currently only able to support irrigation water for a few months per year (Pearce 2015). The GERD's ability to regulate hydrologic variability is also likely to lead to a reduction in property losses due to flooding, especially in Khartoum (Whittington et al. 2015).

Sediment yield from the Upper Blue Nile basin is approximately 131 million t/year (Betrie et al. 2011), and trapping this behind the GERD may cause both positive and negative externalities on downstream countries. Reduced sediment loads will likely extend reservoir life in Sudan and Egypt and lessen silt build-up in irrigation canals; it is estimated that Sudan could save $\$ 50$ million per annum in dredging costs alone (Tesfa 2013; Swanson 2014). Similarly, pumping head to overcome silt build up on irrigated cropland may increase more slowly. Finally, improved water quality and reduced treatment costs for drinking water supply may also result. In contrast, downstream soil fertility is likely to fall, particularly affecting flood-recession agriculture in Sudan (in conjunction with the likely elimination of annual bank flooding), with estimated losses in recession agricultural land on the order of tens of thousands of hectares (J-WAFS 2014).

\section{What Makes the GERD Different?}

Similar to most large dams around the world, the GERD will impose both positive and negative externalities on the Eastern Nile region. The International Commission on Large Dams (ICOLD) estimates that more than 845,000 dams exist globally, with approximately 58,000 registered as large dams (height of $15 \mathrm{~m}$ or more) (Jacquot 2009). Of these large dams, approximately 24,000 are located in China and 9,000 in the United States (ICOLD 2015). In contrast, Sub-Saharan African countries, excluding South Africa, collectively have approximately 500 large dams, with fewer than 10 located in the Blue Nile basin and only three in the Upper Blue Nile basin (Ethiopia). The GERD may thus represent a response to the enormous regional potential for energy production, exceptionally low energy consumption at present, and the importance of energy advancement to strengthen economies and reduce poverty in the region (Africa Progress Report 2015; Kahsay et al. 2015).
The GERD reservoir is to be located in a deep gorge, producing a relatively small surface area considering its volume. This, coupled with relatively cooler temperatures, may serve to constrain evaporation as compared to reservoirs further downstream, particularly those in desert locations. According to Mulat and Moges (2014), the mean annual evaporation at the HAD is nearly $2.4 \mathrm{~m} /$ year, whereas evaporation behind the GERD is expected to be closer to $1.8 \mathrm{~m}$ /year. Studies suggest that storing water in a much cooler environment in the long run may in fact increase Egypt's water supply (Blackmore and Whittington 2008; Jeuland and Whittington 2014). Of course this implies coordinated operations; estimates of mean annual loss from jointly operating the GERD and the HAD may be $16 \%$ less than current losses from the HAD alone (Mulat and Moges 2014).

Ethiopia has not secured external financing to construct the GERD. While some argue this is in response to the project's potential for increasing water conflict in the region (International Rivers 2014), others point to Ethiopia's desire to prove its growing economy and sense of national pride. Thus, Ethiopia has raised funds by selling government bonds to citizens and private companies and by tapping into government reserves. This self-financing may be a unique situation unlike other large dam projects in Africa, in which countries are indebted to foreign lenders for decades after the completion of the project (e.g., the Democratic Republic of Congo's Grand Inga hydropower projects; MONGABAY 2013). However, the result of diverting funding from other sectors and potential projects on the midterm to long-term domestic economy is unclear and warrants further analysis.

Arguably, improved regional cooperation and stability through affordable, available energy may be achievable through this project. Instituting a basin-wide power trade scheme is presented as a way forward that may enhance economic growth and welfare in all Eastern Nile countries (Kahsay et al. 2015). Studies that focus on the hydro-economics of the project conclude that cooperation among riparian countries could significantly increase basin-wide economic benefits (e.g., Arjoon et al. 2014; Kahsay et al. 2015). Ethiopia also has ambitious plan to establish power trade relations with distant nations, including Egypt, South Africa, and even Yemen (Cuesta-Fernández 2015); however, to date infrastructure connections only reach Sudan. Achieving such a high level of interconnection is nontrivial. The required investment costs will be substantial, and the source or potential for financing is unclear.

The availability of relatively constant and predictable release from the GERD under normal operating conditions may particularly benefit Sudan's agriculture and hydropower sectors. Such has been the case for Sudan since the Ethiopian Tekeze Dam on the Atbara River came online, effectively reducing flood-induced losses, trapping silt, and providing farmers sufficient irrigation to plant multiple crops per year (Sudan Vision 2013). Similar positive externalities are expected from the GERD, prompting some within Sudan to extend support for the project given the net national and regional gains (Jemal 2014). This endorsement is remarkable given Ethiopia's initial unilateral decision.

\section{Remaining Challenges}

According to the International Panel on Climate Change (IPCC), historical climatic patterns will likely shift under evolving climate conditions resulting in changes with respect to water resources availability and reliability in the forthcoming decades (IPCC 2012). Considering that typical hydropower project lifecycles exceed 50 years, the possible impact of climate change, both temperature rise and rainfall variability, requires prudent attention 
(Block and Strzepek 2010). Previous studies in the Nile region have consistently indicated projected increases in temperature; however, there appears to be little consensus regarding precipitation and streamflow projections in terms of magnitude, seasonality and direction of change (Satti et al. 2015; Taye et al. 2015). Although climate-change impacts are uncertain, current climate variability (year-to-year) is high, indicating the need to cautiously consider its effects on management and policy during the filling and operation stages. Further studies addressing flexible and adaptable strategies are therefore warranted.

Ethiopia's continued reliance on fuel wood, with some estimates of consumption outpacing replacement (Howell 2011), is continuing to foster highland deforestation. This loss in vegetative cover contributes to increased soil erosion and reduced soil nutrients; potentially leading to reduced agricultural yields, possibly setting up a cycle whereby more land needs to be cleared for agriculture (Howell 2011). Rural electrification may thus promote reduced deforestation and sediment loss rates from the highlands. On the downstream receiving end, sedimentation risks threatening the performance and lifetime of the GERD are not yet well understood. Land-use changes in the upper Blue Nile basin over the past decades, particularly deforestation of natural vegetation and the expansion of agricultural land, have caused significant changes in sediment load (Gebremicael et al. 2013). Based on Betrie et al.'s (2011) model simulations, this sediment yield may be reduced by applying filter strips, stone bunds, and reforestation measures at different subbasins and watershed outlets. Hence, advanced soil-conservation measures upstream of the dam may reduce the consequence of excessive sedimentation on the performance and lifetime of the GERD.

Regarding basin-wide water management, the historical agreements between Egypt and Sudan in 1929 and 1959 need to be revisited, particularly in the context of the Nile Basin Cooperative Framework Agreement (CFA). Currently, Sudan uses less than its allocation according to the 1959 agreement, but this may soon change given Sudan's development plans, climate change, and the GERD (Satti et al. 2015). This adds more pressure to the situation, particularly if decisions are predominantly unilateral. Although travel time between the GERD and HAD is approximately 30 days, there is a need for coordinated operations, particularly during lowflow or high-flow periods, to promote efficiency at both facilities and other sectoral activities (e.g., irrigated agriculture, flood control, etc.; J-WAFS 2014). Remarkably there is still no water-sharing agreement satisfying all riparian countries, which is desperately needed. Improved water accounting may also be justified. Senay et al. (2014) estimate that nearly $97 \mathrm{~km}^{3}$ of water reaches the HAD under natural flow conditions, significantly larger than the often cited $84 \mathrm{~km}^{3}$ value.

Through the Eastern Nile Technical Regional Office (part of the Nile Basin Initiative) the region is encouraged to share data and information with respect to hydro-solidarity principles, which encourages equitable and reasonable utilization of international watercourses. The importance of in situ observational networks for resource assessment and basin management cannot be overstated. The Blue Nile Region in general and the management of GERD in particular will require high quality hydro-meteorological data. Although the availability and quality of historical in situ data are limited and vary from country to country, instituting a framework for open data sharing will improve the understanding and quantification of the spatiotemporal dynamics of the resources. This may lead to more-effective management and operation of resources in the region and facilitate fact-based dialogue among riparian countries. Furthermore, regional countries should take further advantage of available satellite-based data and products that can provide synoptic coverage with a uniform methodology and high level of consistency. The integration of satellite data with in situ measurements could be used as an alternative resource for the Eastern Nile basin to routinely monitor water levels, drought, and flood hazards. In such a hydro-politically tense region, utilizing satellite data may bring trust among riparian countries.

The ongoing construction of the GERD has brought the international spotlight to the Nile basin, with riparian country relations oscillating between contentious and cooperative. How regional planning transpires, in a coordinated cooperative framework or not, will surely set a precedent for future development across the basin. The potential for increasing shared benefits is strong, but collectively realizing those benefits will require an even stronger united will.

\section{References}

Abdelhady, D., et al. (2015). "The Nile and the Grand Ethiopian Renaissance Dam: Is there a meeting point between nationalism and hydrosolidarity?" J. Contemp. Water Res. Educ., 155(1), 73-82.

Abdelhaleem, F., and Helal, E. (2015). "Impacts of Grand Ethiopian Renaissance Dam on different water usages in upper Egypt." $B r . J$. Appl. Sci. Technol., 8(5), 461-483.

Africa Progress Report. (2015). "Power, people, planet: Seizing Africa's energy and climate opportunities." Africa Progress Panel, ISBN 9782-9700821-6-3, 182.

Ahmed, A. T., and Elsanabary, M. H. (2015). "Hydrological and environmental impacts of Grand Ethiopian Renaissance Dam on the Nile River." 18th Int. Water Technology, 336-347.

Arjoon, D., Mohamed, Y., Goor, Q., and Tilmant, A. (2014). "Hydroeconomic risk assessment in the eastern Nile River basin." Water Resour. Econ., 8, 16-31.

Bastawesy, M. E. (2015). "Hydrological scenarios of the Renaissance Dam in Ethiopia and its hydro-environmental impact on the Nile downstream.” J. Hydrol. Eng., 10.1061/(ASCE)HE.1943-5584.0001112, 04014083.

Bekele, S., and Lautze, J. (2009). "Blowback: Ethiopia's Gibe III dam: A balanced assessment,." 〈http://www.latimes.com/opinion/opinion-la/la -oew-lautze4-2009jun04-story.html (Sep. 2, 2015).

Betrie, G. D., Mohamed, Y. A, van Griensven, A., and Srinivasan, R. (2011). "Sediment management modelling in the Blue Nile basin using SWAT model." Hydrol. Earth Syst. Sci., 15(3), 807-818.

Blackmore, D., and Whittington, D. (2008). "Opportunities for cooperative water resources development on the Eastern Nile: Risks and rewards." Independent Rep. of the Scoping Study Team to the Eastern Nile Council of Ministers.

Block, P., and Strzepek, K. (2010). "Economic analysis of large-scale upstream river basin development on the Blue Nile in Ethiopia considering transient conditions, climate variability, and climate change." J. Water Resour. Plann. Manage., 10.1061/(ASCE)WR.1943-5452 .0000022, 156-166.

Bureau of Reclamation. (1964). "Land and water resources of Blue Nile basin: Ethiopia." U.S. Department of Interior, Washington, DC.

Chen, H., and Swain, A. (2014). "The Grand Ethiopian Renaissance Dam: Evaluating its sustainability standard and geopolitical significance." Energy Dev. Front., 3(1), 11-19.

Cuesta-Fernández, I. (2015). "Mammoth dams, lean neighbors: Assessing the bid to turn Ethiopia into East Africa's powerhouse." A new scramble for Africa? S. Scholvin, ed., Ashgate Publishing, Farnham, U.K., 93-110.

Di Falco, S., Yesuf, M., Kohlin, G., and Ringler, C. (2012). "Estimating the impact of climate change on agriculture in low-income countries: Household level evidence from the Nile basin, Ethiopia." Environ. Resour. Econ., 52(4), 457-478.

EAPP (East African Power Pool). (2005). "The EAPP master plan 2011 and grid code" 〈http://eappool.org/about-eapp/〉 (Apr. 26, 2016). 
ENPoE (Ethiopian National Panel of Experts). (2013). "The Grand Ethiopian Renaissance Dam (GERD) and some Egyptian experts' hyperbole." Addis Ababa, Ethiopia.

FDRE (Federal Democratic Republic of Ethiopia). (2008). "Achieving water security: Lessons of Ethiopia country experience, Addis Ababa, Ethiopia." 〈http://www.mowr.gov.et/index.php?pagenum=0.1\&ContentID $=88\rangle($ Jan. 7, 2016).

Fortin, J. (2014). "Dam rising in Ethiopia stirs hope and tension." 〈http:// www.nytimes.com/2014/10/12/world/dam-rising-in-ethiopia-stirs-hope -and-tension.html?_r=0 (May 25, 2016).

Gebremicael, T. G., Mohamed, Y. A., Betrie, G. D., van der Zaag, P., and Teferi, E. (2013). "Trend analysis of runoff and sediment fluxes in the Upper Blue Nile basin: A combined analysis of statistical tests, physically-based models and landuse maps." J. Hydrol., 482, 57-68.

Grey, D., and Sadoff, C. W. (2006). "Water for growth and development." Thematic documents of the III world water forum, Comision Nacional del Agua, Mexico City, Mexico.

Grey, D., and Sadoff, C. W. (2007). "Sink or swim? Water security for growth and development." Water Policy, 9(6), 545-571.

Howell, J. (2011). "Rural electrification and renewable energy in Ethiopia." Environmental Policy Review, Waterville, ME.

ICOLD (International Commission on Large Dams). (2015). "General synthesis, number of dams by country members." 〈http://www.icold-cigb .org/gb/world_register/general_synthesis.asp?IDA=206) (Sep. 2, 2015).

International Rivers. (2014). "The Grand Ethiopian Renaissance Dam fact sheet.” 〈http://www.internationalrivers.org/resources/the-grand-ethiopian -renaissance-dam-fact-sheet-8213〉 (Sep. 2, 2015).

International Rivers. (2015). "Question and answer about large dams." 〈http://www.internationalrivers.org/questions-and-answers-about-large -dams〉 (Sep. 2, 2015).

IPCC (International Panel on Climate Change). (2012). Managing the risks of extreme events and disasters to advance climate change adaptation, Cambridge University Press, Cambridge, U.K.

IWMI (International Water Management Institute). (2016). "Rainfed agriculture summary." 〈http://www.iwmi.cgiar.org/issues/rainfedagriculture/summary/> (Jan. 7, 2016).

Jacquot, J. (2009). "Numbers dams, from Hoover to Three Gorges to the crumbling ones." 〈http://discovermagazine.com/2009/mar/08-dams -hoover-three-gorges-crumbling-ones (Sep. 2, 2015).

Jemal, N. (2014). "Sudan supports GERD until completion-Speaker." 〈http://allafrica.com/stories/201409180184.html〉 (Jan. 7, 2016).

Jeuland, M., and Whittington, D. (2014). "Water resources planning under climate change: Assessing the robustness of real options for the Blue Nile." Water Resour. Res., 10.1002/2013WR013705, 2086-2107.

J-WAFS (Jameel-World Water and Food Security Lab). (2014). "The Grand Ethiopian Renaissance Dam: An opportunity for collaboration and shared benefits in the Eastern Nile basin." Massachusetts Institute of Technology (MIT), Cambridge, MA.

Kahsay, T. N., Kuik, O., Brouwer, R., and Van Der Zaag, P. (2015). "Estimation of the transboundary economic impacts of the Grand Ethiopia Renaissance Dam: A computable general equilibrium analysis." Water Resour. Econ., 10(2015), 14-30.

MoFED (Ministry of Finance and Economic Development). (2010). "The Federal Democratic Republic of Ethiopia Ministry of Finance and economic development growth and transformation plan (GTP)." 2010/112014/15, Addis Ababa, Ethiopia.

MONGABAY. (2013). "Africa to build world's largest dam, but who will benefit?" 〈http://news.mongabay.com/2013/12/africa-to-build-worlds -largest-dam-but-who-will-benefit/> (Sep. 2, 2015).

Mulat, A. G., and Moges, S. A. (2014). "Assessment of the impact of the Grand Ethiopian Renaissance Dam on the performance of the High Aswan Dam." J. Water Resour. Prot., 6(06), 583-598.

Murakami, M. (1995). Managing water for peace in the Middle East: Alternative strategies, United Nations University Press, Tokyo.
National Geographic. (2010). "China's Three Gorges Dam, by the numbers." 〈http://news.nationalgeographic.com/news/2006/06/060609 -gorges-dam_2.html) (Sep. 2, 2015).

NBI (Nile Basin Initiative). (2015). "The cooperative framework agreement for the River Nile basin: An overview." 〈http://www.nilebasin.org/index .php/about-us/the-nb-cooperative-framework $\rangle$ (Jan. 7, 2016).

Pearce, F. (2015). "On the river Nile, a move to avert a conflict over water." 〈http://e360.yale.edu/feature/on_the_river_nile_a_move_to_avert _a_conflict_over_water/2855/> (Sep. 2, 2015).

Sadoff, C. W., et al. (2015). "Securing water, sustaining growth." Rep. of the GWP/OECD Task Force on Water Security and Sustainable Growth, Univ. of Oxford, Oxford, U.K.

Salini Impregilo. (2015). "Grand Ethiopian Renaissance Dam Project.” /http:// www.salini-impregilo.com/en/projects/in-progress/dams-hydroelectric -plants-hydraulic-works/grand-ethiopian-renaissance-dam-project .html\#〉 (Sep. 2, 2015).

Satti, S., Zaitchik, B., and Siddiqui, S. (2015). "The question of Sudan: A hydro-economic optimization model for the Sudanese Blue Nile." Hydrol. Earth Syst. Sci., 19(5), 2275-2293.

Senay, G., Velpuri, N., Bohms, S., Demissie, Y., and Gebremichael, M. (2014). "Understanding the hydrologic sources and sinks in the Nile basin using multisource climate and remote sensing data sets." Water Resour. Res., 50(11), 8625-8650.

SIWI (Stockholm International Water Institute). (2005). "Making water a part of ecomomic development." The economic benefits of improved water management and services, Stockholm, Sweden.

Sudan Vision. (2013). "The Grand Renaissance Dam is not disaster to the Sudan but prosperity." 〈http://news.sudanvisiondaily.com/details.html? rsnpid=225468> (Sep. 3, 2015).

Swanson, A. (2014). The Grand Ethiopian Renaissance Dam: Sustainable development or not? Virginia Tech, Arlington, VA.

Taye, M., Willems, P., and Block, P. (2015). "Implications of climate change on hydrological extremes in the Blue Nile basin: A review." J. Hydrol.: Reg. Stud., 4, 280-293.

Tesfa, B. (2013). "Benefit of Grand Ethiopian Renaissance Dam Project (GERDP) for Sudan and Egypt." EIPSA Communicating Article: Energy, Water, Environment \& Economic.

UNDP (United Nations Development Programme). (2014). "Human development rep. 2014." New York.

USAID (U.S. Agency for International Development). (2015). "What power Africa means for Ethiopia. Ethiopia energy sector overview." 〈https://www.usaid.gov/powerafrica/partners/african-governments/ ethiopia) (Sep. 2, 2015).

Veilleux, J. C. (2013). "The human security dimensions of dam development: The Grand Ethiopian renaissance dam." Global Dialogue, 15(2), 15.

WCD (World Commission on Dams). (2000). Dams and development: A new framework for decision making, Earthscan Publications, London, 356.

Whittington, D., Waterbury, J., and Jeuland, M. (2015). "The Grand Renaissance Dam and prospects for cooperation on the Eastern Nile." Water Policy, 16(4), 595-608.

World Bank. (2006). Ethiopia: Managing water resources to maximize sustainable growth, Water Resources Assistance Strategy, Washington, DC.

World Bank. (2014). "Ethiopia-Geothermal sector development project. Project Appraisal Document." World Bank Group, Washington, DC.

World Bank. (2015). "Electric power consumption (kWh per capita) data." 〈http://data.worldbank.org/indicator/EG.USE.ELEC.KH.PC〉 (Sep. 2, 2015).

Zhang, Y., Block, P., Hammond, M., and King, A. (2015). "Ethiopia's Grand Renaissance Dam: Implications for downstream riparian countries." J. Water Resour. Plann. Manage., 10.1061/(ASCE)WR.19435452.0000520, 05015002. 